\title{
PENGARUH KECUKUPAN MODAL, RISIKO KREDIT, LIKUIDITAS, DAN EFISIENSI OPERASIONAL TERHADAP PROFITABILITAS LPD DI KABUPATEN KARANGASEM
}

\author{
I Ketut Aar Sudarsana ${ }^{1}$ \\ Anak Agung Gede Suarjaya ${ }^{2}$ \\ ${ }^{1,2}$ Fakultas Ekonomi dan Bisnis Universitas Udayana, Bali, Indonesia \\ e-mail: aarsudarsana58@gmail.com
}

\begin{abstract}
ABSTRAK
Penelitian ini bertujuan untuk menganalisis pengaruh kecukupan modal (capital adequacuacy ratio), risiko kredit (non performing loan), likuiditas (loan to deposit ratio), dan efisiensi operasional (BOPO) terhadap profitabilitas LPD di Kabupaten Karangasem. Penelitian ini dilakukan pada semua LPD se-Kabupaten Karangasem periode 2015-2017. Jumlah sampel yang digunakan sebanyak 108 LPD melalui metode probability sampling dengan Teknik cluster sampling (area sampling). Penelitian ini menggunakan metode observasi non partisipant dan menggunakan analisis regresi linier berganda. Berdasarkan hasil analisis penelitian ini menunjukkan bahwa secara parsial kecukupan modal dan likuiditas berpengaruh positif signifikan terhadap return on asset pada LPD di Kabupaten Karangasem periode 2015-2017. Risiko kredit dan efisiensi operasional secara parsial berpengaruh negatif signifikan terhadap ROA pada LPD Kabupaten Karangasem.

Kata kunci: kecukupan modal, risiko kredit, likuiditas, efisiensi operasional, profitabilitas
\end{abstract}

\begin{abstract}
This study aims to analyze the effect of capital adequacy (capital adequacy ratio), credit risk (non-performing loan), liquidity (loan to deposit ratio), and operational efficiency (BOPO) on LPD profitability in Karangasem Regency. This research was conducted in all LPDs throughout the Karangasem Regency for the period 2015-2017. The number of samples used was 108 LPD through probability sampling method with cluster sampling technique (sampling area). This study uses a non-participant observation method and uses multiple linear regression analysis. Based on the results of the analysis, this study shows that partially capital adequacy and liquidity have a significant positive effect on return on assets in the LPD in Karangasem Regency for the period 2015-2017. Credit risk and operational efficiency partially have a significant negative effect on ROA in Karangasem Regency LPD. Keywords: capital adequacy, credit risk, liquidity, operational efficiency, profitability
\end{abstract}




\section{PENDAHULUAN}

Peran dari ekonomi pedesaan memiliki pengaruh yang erat terhadap pembangunan dan perekonomian di Indonesia, karena terlaksananya pembangunan di Indonesia berawal dari perekonomian pedesaan. Daerah pedesaan memiliki banyak potensi yang dapat menunjang pertumbuhan dan kelancaran pembangunan nasional (Sujana, 2014). Keberhasilan pembangunan desa diharapkan dapat menciptakan pemerataan pembangunan sesuai dengan program pemerintah pusat untuk dapat meningkatkan taraf hidup masyarakat desa. Peningkatan pembangunan di pedesaan sangat dibutuhkan guna untuk memberdayakan perekonomian desa yang lebih optimal.

Bali merupakan salah satu provinsi yang ada di Indonesia yang terkenal akan kebudayaan yang dimiliki, salah satu keunikan di Bali adalah eksistensi dari desa pakraman. Lingkup desa pakraman tidak terbatas dari peran-peran kebudayaan dan juga keagamaan, melainkan juga ekonomi dan pelayanan umum yang berasal dari pemerintah. Untuk menunjang perekonomian pedesaan serta memperlancar pembangunan perekonomian, maka pemerintah perlu untuk menyediakan lembaga keuangan yang dapat memberikan pinjaman dan menampung keperluan keuangan masyarakat pedesaan.

Lembaga keuangan adalah setiap perusahaan yang bergerak dan menghimpun dana, menyalurkan dana atau kedua-duanya (Kasmir, 2012 : 12). Kegiatan yang dilakukan oleh lembaga keuangan selalu berkaitan dengan bidang keuangan. Lembaga keuangan memiliki peranan penting dalam kondisi perekonomian di Indonesia maupun daerah. Keberadaan lembaga keuangan yang mampu menampung dan memberikan pinjaman sebagai sebuah wadah untuk mengatasi seluruh kebutuhan keuangan masyarakat merupakan cara yang dapat dilakukan untuk menunjang dan memperlancar pembangunan ekonomi suatu daerah pedesaan (Asri \& Suarjaya, 2018).

Tingkat pertumbuhan ekonomi di Indonesia tidak dapat dipisahkan dengan adanya peranan dari lembaga keuangan, baik lembaga keuangan bank maupun lembaga non bank. Lembaga Perkreditan Desa (LPD) merupakan lembaga keuangan non bank yang hanya terdapat di Bali. Pada tahun 1984 dengan Surat Keputusan (SK) Gubernur No. 972 Tahun 1984 tentang Pendirian Lembaga Perkreditan Desa (LPD) di Provinsi Daerah Tingkat I Bali. Proyek pendirian LPD mulai dilakukan dan keberadaan LPD diatur dibawah Peraturan Daerah (PERDA) yakni Peraturan Daerah Provinsi Bali Nomor 3 Tahun 2007.

Peraturan Daerah Provinsi Bali No. 4 Tahun 2012 Tentang Perubahan Kedua atas perda No. 8 tahun 2002 tentang LPD sudah tidak sesuai dengan dengan perkembangan hukum dan masyarakat sehingga digantikan dengan Perda terbaru yaitu Peraturan Daerah Provisi Bali Nomor 3 Tahun 2017. Perda tersebut mengatur mengenai syarat-syarat pendirian LPD. Berdasarkan Peraturan Gubernur Bali No. 44 Tahun 2017, LPD adalah lembaga keuangan milik desa pakraman yang melaksanakan kegiatan usaha di lingkungan desa pakraman yang melaksanakan kegiatan usaha di lingkungan desa dan untuk krama desa.

LPD merupakan salah satu unsur kelembagaan desa pakraman yang menjalankan fungsi keuangan desa untuk mengelola potensi keuangan. LPD telah berkembang dengan pesat dan telah memberi manfaat yang luas bagi masyarakat. 
Melakukan kegiatan operasinya LPD memiliki tujuan jangka pendek dan jangka panjang. Tujuan jangka pendek dari LPD yaitu untuk menyejahterakan masyarakat dan mendapatkan keuntungan yang besar dan untuk tujuan jangka panjangnya yaitu mempertahankan kontuitas usahanya (Sujana, 2014). Fungsi dari LPD yaitu menghimpun dana masyarakat melalui tabungan dan deposito serta mengalokasikan dana tersebut agar mencapai tingkat profitabilitas.

LPD merupakan penghimpun dana desa pakraman yang bertujuan menyejahterakan masyarakat desa pakraman. LPD dimiliki oleh desa pakraman, dikelola dan untuk desa pakraman. Hal itu menunjukkan LPD adalah lembaga keuangan yang diakui oleh PERDA dan sebagai lembaga keuangan yang bersifat khusus, karena kegiatannya usahanya hanya di lingkungan desa pakraman (Asri \& Suarjaya, 2018). Karangasem merupakan salah satu Kabupaten yang terkenal akan kerajinan, keseniaan, kebudayaan, serta objek wisata alam yang dimiliki. Keberadaan LPD ditengah-tengah kehidupan masyarakat Kabupaten Karangasem memberikan manfaat dalam meningkatkan perekonomian desa. LPD dapat membantu masyarakat Kabupaten Karangasem dalam menjalankan kegiatan simpan pinjam di LPD. Kabupaten Karangasem memiliki jumlah LPD yang cukup banyak. Penyebaran LPD disetiap Kecamatan dapat dilihat pada Tabel 1 sebagai berikut;

Tabel 1.

\section{Penyebaran LPD Kabupaten Karangasem berdasarkan Kecamatan tahun} 2017

\begin{tabular}{ccc}
\hline No & Kecamatan & Jumlah LPD \\
\hline 1 & Abang & 20 \\
2 & Bebandem & 15 \\
3 & Karangsem & 23 \\
4 & Kubu & 41 \\
5 & Manggis & 19 \\
6 & Rendang & 26 \\
7 & Selat & 27 \\
8 & Sidemen & 19 \\
& Jumlah & $\mathbf{1 9 0}$ \\
\hline
\end{tabular}

Sumber: LPLPD Kabupaten Karangasem, 2017

Berdasarkan Tabel 1. Kabupaten Karangasem memiliki 8 kecamatan dengan jumlah 190 LPD yang berada disetiap desa di Kabupaten Karangasem. Dari 190 LPD tersebut diklasifikasikan dalam beberapa kategori berdasarkan penilaian kinerja LPD.

Pada Tabel 2. terlihat bahwa LPD dengan keterangan sehat mengalami penurunan dari tahu 2015-2017 dan LPD dengan kondisi cukup sehat, kurang sehat dan tidak sehat mengalami fluktuasi dari tahun 2015-2017. Sedangkan LPD yang tidak beroperasi mengalami penurunan dari tahun 2015-2017, hal ini dikarenakan kurangnya kinerja keuangan dari LPD. Kinerja keuangan LPD yang baik memerlukan adanya pengelolaaan manajemen yang baik pada LPD. Perkembangan LPD di Kabupaten Karangasem tak luput dari beberapa permasalahan, diantaranya adanya perbedaan jumlah pertumbuhan aset LPD dimana beberapa LPD memiliki 
aset dengan jumlah besar dan lainnya memiliki aset relatif sedikit, selain itu kecukupan modal beberapa LPD masih belum terpenuhi.

Tabel 2.

Jumlah LPD sehat, Cukup Sehat, Kurang Sehat, Tidak Sehat, Tidak Beroperasi (macet) Periode 2015-2017

\begin{tabular}{cccc}
\hline Kategori & $\mathbf{2 0 1 5}$ & Periode & $\mathbf{2 0 1 7}$ \\
\hline Sehat & 103 & 112 & 94 \\
Cukup Sehat & 41 & 37 & 52 \\
Kurang sehat & 12 & 17 & 15 \\
Tidak Sehat & 2 & 0 & 6 \\
Tidak Operasi & 32 & 24 & 23 \\
Jumlah & $\mathbf{1 9 0}$ & $\mathbf{1 9 0}$ & $\mathbf{1 9 0}$ \\
\hline
\end{tabular}

Sumber: LPLPD Kabupaten Karangasem, 2017

Kemampuan untuk menumbuhkan kepercayaan masyarakat terhadap LPD dapat dilakukan dengan menunjukan kinerja keuangan LPD tersebut, dimana kinerja keuangan merupakan suatu analisis yang dilakukan untuk melihat sejauh mana suatu perusahaan telah melaksanakan dengan menggunakan aturan-aturan pelaksanaan keuangan secara baik dan benar. LPD berusaha meningkatkan pelayanan kepada masyarakat dan memperoleh keuntungan dari pemberian kredit atau pinjaman, menerima deposito pinjaman dalam jangka waktu tertentu serta melayani tabungan dari anggota masyarakat.

Profitabilitas merupakan indikator yang paling tepat digunakan untuk mengukur kinerja LPD. Profitabilitas menunjukkan kemampuan perusahaan memperoleh laba atau ukuran efektivitas pengelolaan manajemen perusahaan (Wiagustini, 2014:86). (Brigham \& Houston, 2009:197) mendifinisikan profitabilitas adalah hasil akhir dari sejumlah kebijakan dan keputusan yang dilakukan perusahaan. Profitabilitas dalam penelitian ini di ukur dengan menggunakan return on asset (ROA). ROA merupakan proksi dari profitabilitas yang paling penting dalam perbankan dibandingkan proksi profitabilitas lainnya. Tingginya tingkat Return on Asset menunjukkan tingkan return yang diterima bank juga tinggi. ROA adalah rasio profitabilitas yang menunjukkan perbandingan antara laba tahun berjalan dengan total aset LPD, rasio ini menunjukkan tingkat efisiensi penegelolaan asset yang dilakukan oleh bank bersangkutan (Riyadi, 2006:156).

Berdasarkan Tabel 3. dapat dilihat ROA yang terjadi pada LPD Kabupaten Karangasem dari tahun 2015-2017, mengalami penurunan dan berfluktuasi pada beberapa Kecamatan. Pada Kecataman Abang, Bebandem, Kubu, dan Selat mengalami penurunan ROA dari tahun 2015-2017, sedangkan pada Kecamatan Karangasem, Manggis, Rendang, dan Sidemen mengalami fluktuasi dari tahun 2015 sampai dengan tahun 2017. Hal tersebut menunjukkan bahwa LPD di Kabupaten Karangasem mengalami kesulitan untuk menjaga stabilitas pertumbuhan laba disetiap tahunnya. Fenomena ini yang mendorong peneliti melakukan penelitian di LPD Kabupaten Karangasem sebagai lokasi penelitian, untuk mengetahui adakah pengaruh kecukupan modal, risiko kredit, likuiditas, dan biaya operasional pendapatan operasional terhadap profitabilitas. 
Tabel 3.

Data ROA LPD di Kabupaten Karangasem berdasarkan Kecamatan periode 2015-2017

\begin{tabular}{ccccc}
\hline & & & ROA (\%) & \\
No & Kecamatan & $\mathbf{2 0 1 5}$ & $\mathbf{2 0 1 6}$ & $\mathbf{2 0 1 7}$ \\
\hline 1 & Abang & 4,53 & 4,47 & 4,04 \\
2 & Bebandem & 3,73 & 3,56 & 2,51 \\
3 & Karangsem & 4,19 & 4,25 & 3,97 \\
4 & Kubu & 4,06 & 3,78 & 3,27 \\
5 & Manggis & 4,07 & 4,13 & 4,02 \\
6 & Rendang & 2,73 & 2,93 & 2,50 \\
7 & Selat & 2,79 & 2,73 & 1,92 \\
8 & Sidemen & 2,05 & 2,22 & 2,17 \\
& Jumlah & $\mathbf{2 8 , 1 5}$ & $\mathbf{2 8 , 0 6}$ & $\mathbf{2 4 , 4 0}$ \\
\hline
\end{tabular}

Sumber: LPLPD Kabupaten Karangasem, 2017

Salah satu kegiatan untuk dapat meningatkan profitabilitas adalah adanya modal LPD yang memadai dalam melakukan operasionalnya. Tingkat kecukupan modal yang memadai dapat melindungi sebuah bank ketika mengalami kerugian dari aktifitas operasional yang tidak terduga (Anjani, 2014). Kecukupan modal LPD dapat diukur dengan Capital Adequacy Ratio (CAR) adalah rasio kewajiban pemenuhan modal minimum yang harus dimiliki oleh bank (Riyadi, 2006:159). Semakin tinggi CAR maka semakin baik kemampuan LPD tersebut untuk menanggung risiko dari setiap aktiva produktif yang berisiko. Jika nilai CAR tinggi maka LPD tersebut mampu membiayai kegiatan operasional dan memberikan kontribusi yang cukup besar bagi profitabilitas. Menurut (Sudirman, 2013:115) modal yang ada dalam suatu lembaga usaha mempunyai fungsi untuk melakukan kegiatan produksi yang menghasilkan pendapatan perusahaan.

Penelitian yang dilakukan oleh Capraru \& Ihnatov (2014) menemukan bahwa CAR berpengaruh positif dan signifikan terhadap profitabilitas bank. Hasil penelitian tersebut didukung oleh Houssem (2014) yang juga menemukan bahwa CAR berpengaruh positif terhadap profitabilitas. Penemuan tersebut dipekuat lagi oleh Hasil penelitian dari Roman \& Danuletiu (2013), Francis (2013), Damayanti (2012), Ani, et al. (2012) menemukan bahwa variabel CAR memiliki hubungan yang positif dengan profitabilitas. Penelitian tersebut kontradiktif dengan penelitian yang dilakukan oleh Almumani (2013) menemukan bahwa tidak ada hubungan yang positif antara CAR dengan profitabilitas. Penelitian yang dilakukan oleh Prasanjaya \& Ramantha (2013) menemukan hal yang sama bahwa CAR tidak berpengaruh signifikan terhadap profitabilitas. Penelitian Putrianingsih (2016), Alper \& Anbar (2011) menemukan bahwa CAR berpengaruh negatif dan signifikan terhadap profitabilitas.

Faktor lain dalam kegiatan utama LPD untuk dapat meningkatkan profitabilitas adalah pemberian kredit. Salah satu kegiatan bank sebagai lembaga intermediasi adalah melakukan penyaluran kredit untuk meningkatkan profitabilitas Pemberian kredit selain sumber dari pendapatan juga sangat rentan terhadap risiko yang dapat menjadi salah satu penyebab utama LPD menghadapi masalah. Kredit yang bermasalah berakibat pada kerugian karena tidak diterimanya kembali dana yang telah disalurkan maupun pendapatan bunga sehingga terjadinya 
penurunan pendapatan secara total (Ismail, 2009:222). Masalah dalam aktivitas pemberian kredit disebut risiko kredit. Risiko kredit merupakan suatu risiko kerugian yang disebabkan oleh ketidakmampuan dari debitur atas kewajiban pembayaran utang baik utang pokok maupun bunganya. Risiko kredit dapat diukur menggunakan Non Performing Loan (NPL) merupakan rasio yang menunjukkan kemampuaan manajemen mengelola kredit bermasalah yang diberikan bank.

Dampak dari keberadaan NPL yang tidak wajar salah satunya adalah hilangnya kesempatan memperoleh income (pendapatan) dari kredit yang diberikan, sehingga mengurangi perolehan laba dan berpengaruh buruk bagi profitabilitas bank (Dendawijaya, 2005). NPL adalah perbandingan antara jumlah kredit yang diberikan dengan tingkat kolektibilitas 3 (tiga) sampai dengan 5 (lima) dibandingkan dengan total kredit yang diberikan oleh bank. Hasil penelitian yang dilakukan oleh Peling \& Sedana (2018) menemukan bahwa NPL berpengaruh negatif dan signifikan teradap ROA. Penelitian tersebut didukung Yanti (2015) menemukan bahwa NPL berpengaruh negatif dan signifikan terhadap profitabilitas. Penelitian tersebut diperkuat kembali oleh penelitian (Anggreni \& Suardhika, 2014), Roman \& Danuletiu (2013), Sukma (2013), menemukan bahwa NPL berpengaruh negatif dan signifikan terhadap profitabilitas. Berbeda dengan penelitian yang dilakukan Duraj \& Moci (2015) menemukan bahwa NPL tidak memiliki hubungan dengan profitabilitas.

Likuiditas merupakan kemampuan perusahaan untuk memenuhi kewajiban finansialnya dalam jangka pendek dengan dana lancar yang tersedia (Wiagustini, 2014: 99). Likuiditas yang tidak memadai adalah salah satu alasan utama kegagalan bank. Bank yang tidak memiliki masalah kekurangan likuiditas akan memberikan dampak yang positif terhadap kepercayaan masyarakat sehingga kesempatan bank untuk meningkatkan keuntungan akan sangat besar (Sujana, 2014)

Loan to Deposit Rasio (LDR) digunakan untuk mengukur dalam menilai kemampuan bank dalam menjalankan usaha atau kegiatan operasionannya. LDR adalah rasio untuk mengukur besarnya jumlah kredit yang disalurkan dibandingkan dengan jumlah dana masyarakat dan modal sendiri yang digunakan (Kasmir, 2012 : 225). Tinggi rendahnya LDR itu berarti banyaknya pemberian pinjaman yang disalurkan dan akan berpengaruh terhadap tingkat profitabilitas LPD. Penelitian yang dilakukan Alper \& Anbar (2011), Rengasamy (2014) dan Pratiwi (2015) likuiditas menunjukan tidak adanya dampak yang signifikan terhadap profitabilitas bank. Penelitian Almumani (2013) menemukan bahwa likuiditas memiliki hubungan yang negatif dan tidak signifikan terhadap profitabilitas. Berbeda dengan penelitian yang dilakukan Cristina \& Artini (2018), Peling \& Sedana (2018), Asri \& Suarjaya (2018) menemukan bahwa Likuiditas berpengaruh positif dan signifikan terhadap profitabilitas. Penelitian tersebut didukung oleh penelitian Damayanti (2012) menemukan bahwa LDR berpengaruh positif dan signifikan terhadap profitabilitas.

Penilaian tingkat kesehatan bank salah satunya dilakukan melalui penilaian terhadap komponen rasio BOPO (Prasetyo \& Darmayanti, 2015). Biaya Operasional Pendapatan Operasional (BOPO) digunakan untuk menilai kehematan belanja LPD yaitu prosentase perbandingan antara biaya operasional terhadap biaya operasional LPD (Perda No. 3. Tahun 2017). Rasio BOPO digunakan untuk 
mengukur tingkat efiensi dan kemampuan LPD dalam melakukan kegiatan operasinya. Semakin rendah tingkat rasio BOPO berarti semakin baik kinerja manajemen bank tersebut, karena lebih efisien dalam menggunakan sumberdaya yang ada diperusahaan (Riyadi, 2006:159)

Tingginya tingkat BOPO menunjukkan buruknya kinerja LPD dalam memanajemen perusahaannya. Hal ini dapat mengakibatkan hilangnya kepercayaan masyarakat dalam melakukan simpan pinjam di LPD, sehingga dapat mengganggu perolehan laba dari LPD tersebut. Hasil penelitian yang dilakukan oleh Prasanjaya \& Ramantha (2013) menemukan bahwa BOPO berpengaruh signifikan terhadap profitabilitas. Penelitian yang dilakukan Porawouw (2014) menemukan BOPO berpengaruh positif signifikan terhadap profitabilitas. Hasil berbeda diperoleh oleh penelitian yang dilakukan Peling \& Sedana (2018) menemukan bahwa BOPO berpengaruh negatif dan signifikan terhadap profitabilitas. Penelitian tersebut diperkuat kembali oleh Prasetyo \& Darmayanti (2015), Zulfiah \& Joni (2014), menemukan bahwa BOPO berpengaruh negatif terhadap profitabilitas.

Profitabilitas merupakan kemampuan bank untuk menghasilkan atau memperoleh laba secara efektif dan efisien dalam kegiatan operasionalnya. Profitabilitas sutau perusahaan menunjukkan perbandingan antara laba dengan aktiva atau modal yang menhasilkan laba tersebut (Riyanto, 2008:35). Menurut Sartono (2014:122) profitabilitas adalah kemampuan perusahaan memperoleh laba dalam hubungannya dengan penjualan, total aktiva maupun modal sendiri. Tingginya tingkat profitabilitas mencerminkan kinerja keuangan perusahaan yang baik dan mampu meningkatkan daya saing perusahaan. Jadi dapat disimpulkan bahwa profitabilitas merupakan kemampuan perusahaan untuk memperoleh laba atau keuntungan melalui kegiatan operasional dari perusahaan. Maka setiap perusahaan akan selalu berusaha meningkatkan profitabilitasnya, karena semakin tinggi nilai profitabilitas maka perusahaan akan memiliki prospek yang baik di masa depan.

Modal merupakan salah satu faktor yang penting bagi bank dalam menegembangkan usahanya dan menampung resiko kerugian. Modal sebagai cadangan atau back up dana jika bank mengalami kesulitan. Posisi modal bank menjadi jaminan bagi masyarakat yang berniat menyimpan dananya diperbankan, sehingga dengan adanya setoran modal dari pemegang saham maka masyarakat akan percaya untuk menyetor dananya (Sukma, 2013). Menurut Riyadi (2006:161) CAR yaitu rasio kewajiban pemenuhan modal minimum yang harus dimiliki oleh bank. Dendawijaya (2009:121) menyatakan CAR merupakan rasio kinerja bank untuk mengukur rasio kecukupan modal minimum yang harus dimiliki oleh bank dalam menunjang aktiva yang mengandung atau menghasilkan risiko, seperti kredit. Apabila nilai CAR tinggi maka bank tersebut mampu membiayai operasi bank dan keadaan yang menguntungkan tersebut dapat memberikan kontribusi bagi profitabilitas.

Berdasarkan Peraturan Gubernur Bali No 11 Tahun 2013 LPD harus memenuhi kecukupan modal minimun 12 persen dan berdasarkan perbandingan antara modal LPD dengan ATMR. Penilaian terhadap fator permodalan didasarkan pada rasio modal terhadap Aktiva Tertimbang Menurut Risiko (ATMR) 
(Riyadi,2006:171). ATMR adalah total nilai masing-masing aktiva setelah dikalikan dengan masing-masing bobot aktiva tersebut.

Pemberian kredit merupakan salah satu pendapatan utama dari bank melalui bunga yang didapatkan oleh pihak bank melalui debitur. Perkembangan pemberian kredit yang paling tidak menyenangkan bagi pihak bank adalah apabila kredit yang diberikannya menjadi kredit bermasalah. Hal ini terutama disebabkan oleh kegagalan pihak debitur memenuhi kewajibannya untuk membayar angsuran (cicilan) pokok kredit beserta bunga yang telah disepakati kedua belah pihak dalam perjanjian kredit (Dendawijaya, 2009:82).

Risiko bank dalam pemberian kredit yakni salah satunya tidak lancarnya pembayaran kredit. Risiko ini disebut dengan risiko kredit. Kredit yang bermasalah dapat diukur dari kolektibilitasnya (Cristina, 2018). Risiko kredit diukur dengan Non performing loan (NPL). Menurut Ismail (2009:224), kredit bermasalah sering juga disebut dengan NPL dimana nasabah sudah tidak sanggup membayar sebagian atau seluruh kewajibannya kepada bank seperti yang telah diperjanjikan. NPL memiliki peranan penting didalam manajemen bank, karena peningkatan NPL yang dialami perbankkan akan menyebabkan tersendatnya penyaluran kredit. Menurut Riyadi (2006:161) NPL mencerminkan risiko kredit, dimana semakin kecil NPL semakin kecil pula risiko kredit yang ditanggung pihak bank.

Kemampuan bank dalam mengelola likuiditasnya akan berdampak terhadap kepercayaan masyarakat kepada bank itu sendiri sehingga akan membantu kelangsungan operasional maupun keberadaan bank tersebut. Salah satu penilaian likuiditas LPD dengan menggunakan LDR. LDR adalah rasio untuk mengukur komposisi jumlah kredit yang diberikan dibandingkan dengan jumlah dana masyarakat dan modal sendiri yang digunakan (Kasmir, 2012:130). Selain itu LDR merupakan ukuran kemampuan bank dalam membayar kembali penarikan dana yang dilakukan deposan dengan mengandalkan kredit yang diberikan sebagai sumber likuiditasnya (Dendawijaya, 2009:290). LDR dapat menunjukkan kemampuan bank dalam menyalurkan dana pihak ketiga yang dihimpun bank. Tujuan dari perhitungan LDR adalah untuk mengetahui seberapa jauh suatu LPD dikatakan memiliki kondisi yang sehat dalam menjalankan kegiatan operasionalnya.

Berdasarkan PBI No. 18/14/PBI/2016 menyatakan bahwa batas aman untuk nilai LDR adalah 78-92 persen. Apabila LDR diatas 92 persen artinya likuiditas LPD kurang baik karena jumlah DPK tidak mampu memenuhi targer dalam menyalurkan kreditnya. Riyadi (2006:165) menyatakan LDR akan menunjukkan tingkat kemampuan bank dalam menyalurkan dana pihak ketiga yang dihimpun oleh bank yang bersangkutan.

Tingginya tingkat LDR menunjukkan lembaga keuangan tersebut dalam kondisi illikuid dimana, perusahaan tidak mampu memenuhi kewajibannya, sebaliknya tingkat rasio yang rendah menunjukkan bank dalam kondisi likuid berarti perusahaan tersebut mampu memenuhi kewajibannya (Kasmir, 2012:130). Besar kecilnya LDR suatu lembaga keuangan akan memepengaruhi nilai profitabilitasnya. Kecilnya dana yang disalurkan melalui kredit kepada nasabah maka jumlah dana yang mengganggur akan semakin bertambah sehingga laba akan menurun yang diperoleh melalui penyaluran kredit. 
Rasio BOPO digunakan untuk mengukur efisiensi operasional bank, dengan membandingkan biaya operasional terhadap pendapatan operasional. Biaya operasional merupakan biaya yang dikeluarkan oleh pihak bank dalam menjalankan aktivitasnya sehari-hari, sedangkan pendapatan operasional merupakan pendapatan yang diterima oleh pihak bank yang diperoleh melalui penyaluran kredit dalam bentuk suku bunga.

Penilaian tingkat kesehatan LPD dilakukan melalui penilaian dari rasio BOPO. Menurut Dendawijaya (2009:119) BOPO adalah perbandingan antara biaya operasional dengan pendapatan operasional. Apabila rasio BOPO yang dihasilkan semakin rendah maka kinerja dari LPD tersebut semakin baik pula.

Biaya operasional merupakan seluruh biaya yang dikeluarkan oleh LPD untuk menjalankan aktivitas usaha meliputi biaya bunga, gaji, biaya pemasaran dan lain-lain), sedangkan pendapatan operasional merupakan pendapatan utama dari LPD yaitu pendapatan bunga yang diperoleh dari penempatan dana dalam bentuk kredit dan penempatan operasi lainnya.

Pemodalan merupakan faktor yang sangat penting dimana menunjukkan kemampuan manajemen bank untuk mengawasi serta mengontrol risiko yang terjadi, yang bisa mempengaruhi besarnya modal bank . Kecukupan modal tercemin pada Capital Adequacy Ratio (CAR). CAR mencerminkan modal sendiri untuk mengahasilkan laba. Semakin besar CAR maka semakin besar kesempatan dalam menghasilkan laba karena dengan modal yang besar, manajemen sendiri sangat leluasa dalam menempatkan dananya kedalam aktivitas investasi yang menguntungkan. Apabila nilai CAR tinggi berarti bank tersebut mampu membiayai operasi bank, dan keadaan menguntungkan tersebut dapat memeberikan kontribusi yang cukup besar bagi profitabilitas bank yang bersangkutan (Dendawijaya, 2009:144). Pembentukan dan peningkatan peranan aktiva bank sebagai penghasil keuntungan harus memperhatikan kepentingan pihak-pihak ketiga sebagai pemasok modal.

Teori diatas didukung oleh Hasil penelitian dari Houssem (2014), Capraru \& Ihnatov (2014) menemukan bahwa CAR berpengaruh positif terhadap profitabilitas. Hasil penelitian tersebut didukung, Roman \& Danuletiu (2013), Francis (2013) menemukan bahwa variabel CAR memiliki hubungan yang positif dengan profitabilitas. Penemuan tersebut dipekuat lagi oleh penelitian yang dilakukan Damayanti (2012), Ani et al. (2012) menemukan bahwa Capital Adequacy Ratio (CAR) berpengaruh positif dan signifikan terhadap profitabilitas. Berdasarkan teori serta penelitian yang sudah dipaparkan, hipotesis dari penelitian ini adalah

$\mathrm{H}_{1}$ : Kecukupan Modal berpengaruh positif dan signifikan terhadap profitabilitas.

Pemberian kredit merupakan kegiatan utama LPD dalam kegiatannya untuk memperoleh laba, maka dari itu dalam memberikan kredit LPD harus megetahui kemampuan masyarakat desa untuk memenuhi kewajibannya dalam pembayaran kredit. Jika kewajiban pembayaran kredit bermasalah disitulah terjadi sebuah risiko dalam pemberian kredit yang disebut dengan risiko kredit.

Risiko kredit tercermin dalam Non Performing loan (NPL). NPL merupakan salah satu pengukuran dari rasio risiko usaha yang menunjukkan besarnya risiko kredit bermasalah yang ada pada suatu LPD. Menurut (Riyadi, 2006:161) NPL 
mencerminkan risiko kredit, dimana semakin kecil NPL semakin kecil pula risiko kredit yang ditanggung pihak bank. Jika semakin tinggi NPL, maka semakin tinggi tunggakan kredit yang berpotensi menurunkan pendapatan bunga.

Berdasarkan teori yang sudah dijelaskan Hasil Penelitian yang dilakukan Yanti (2015), Anggreni \& Suardhika (2014) menemukan bahwa NPL berpengaruh negatif dan signifikan terhadap profitabilitas. Penelitian tersebut didukung juga oleh Roman \& Danuletiu (2013), Sukma (2013) menemukan bahwa NPL berpengaruh negatif dan signifikan terhadap profitabilitas. Berdasarkan teori dan hasil penelitian yang telah dilakukan sebelumnya, maka hipotesis dalam penelitian ini adalah:

$\mathrm{H}_{2}$ : Risiko Kredit berpengaruh negatif dan signifikan terhadap Profitabilitas

Analisis likuiditas adalah analisis yang dilakukan terhadap kemampuan bank dalam memenuhi kewajiban jangka pendeknya atau kewajiban yang sudah jatuh tempo (Dendawijaya, 2005:104). Menurut Prasanjaya \& Ramantha (2013), Kurangnya likuiditas adalah salah satu alasan utama kegagalan bank. LDR yang tinggi akan menunjukkan profitabilitas yang besar, karena kredit yang disalurkan oleh bank dapat dijalankan secara efektif. Semakin tinggi tingkat LDR dengan tetap sesuai batas yang telah ditentukan oleh Bank Indonesia dan didukung dengan kualitas penyaluran kredit yang baik oleh bank, spread based yang di peroleh bank akan meningkat, sehingga nantinya meningkatkan profitabilitasnya (Peling \& Sedana, 2018)

Penelitian yang dilakukan Cristina \& Artini (2018), Peling \& Sedana (2018), Asri \& Suarjaya (2018) menemukan bahwa Likuiditas berpengaruh positif dan signifikan terhadap profitabilitas. Penelitian tersebut didukung oleh penelitian Damayanti (2012) menemukan bahwa LDR berpengaruh positif dan signifikan terhadap profitabilitas. Berdasarkan teori dan hasil penelitian yang dilakukan sebelumnya, maka hipotesis dalam penelitian ini adalah

$\mathrm{H}_{3}$ : Likuiditas berpengaruh positif terhadap profitabilitas

Menurut Wibowo (2013) Rasio BOPO menunjukkan efisiensi bank dalam menjalankan usaha pokoknya terutama kredit, dimana bunga kredit menjadi pendapatan terbesar perbankan. Semakin kecil BOPO menunjukkan semakin efisien bank dalam menjalankan aktivitas usahanya. Semakin tinggi biaya pendapatan berarti kegiatan operasionalnya semakin tidak efisien sehingga pendapatanya juga semakin kecil.

Penelitian Peling \& Sedana (2018), Prasetyo \& Darmayanti (2015), Wibowo (2013) menemukan bahwa BOPO berpengaruh negatife signifikan terhadap profitabilitas. Penelitian yang dilakukan Zulfiah \& Joni (2014) menemukan bahwa BOPO berpengaruh negatif terhadap profitabilitas. Berdasarkan penelitianpenelitian yang sudah dipaparkan, hipotesis dari penelitian ini adalah

$\mathrm{H}_{4}$ : Efisiensi Operasional berpengaruh negatif dan signifikan terhadap profitabilitas

\section{METODE PENELITIAN}

Lokasi penelitian dilakukan pada LPD di Kabupaten Karangasem. Penelitian ini menggunakan laporan keuangan yang diperoleh dari Lembaga Pemberdayaan Lembaga Perkreditan Desa (LPLPD) Kabupaten Karangasem. Objek penelitian ini yaitu tingkat Profitabilitas LPD Kabupaten Karangasem Periode 2015-2017 yang 
diproksikan dengan Return on Asset (ROA) yang dihubungkan dengan menggunakan kecukupan modal, risiko kredit, likuiditas, dan efisiensi operasional. Dalam penelitian ini rasio profitabilitas dihitung menggunakan Return on Asset (ROA) yaitu dengan membandingkan laba bersih tahun berjalan dengan total aktiva yang digunakan pada LPD di Kabupaten Karangasem periode 2015-2017 dalam satuan persentase, dimana Profitabilitas dihitung dengan rumus sebagai berikut (Perda No 3 Tahun 2017)

$$
\text { Return on Assets }=\frac{\text { Laba Tahun Berjalan }}{\text { Total Aktiva(Rata-Rata Assets })} \times 100 \%
$$

Besarnya CAR dapat dihitung dengan rumus (Perda No 3 Tahun 2017)

$$
C A R=\frac{\text { Modal } L P D}{A T M R} \times 100 \%
$$

Untuk menghitung NPL dengan rumus sebagai berikut:

$$
N P L=\frac{\text { Total Kredit Bermasalah }}{\text { Total Kredit Yang Diberikan }} \times 100 \%
$$

Satuan yang digunakan LDR adalah persentase dan formulasi berdasarkan rumus sebagai berikut (Perda No 3 Tahun 2017)

$$
L D R=\frac{\text { Total Pinjaman Yang Diberikan }}{\text { Total DPK+Modal Inti }} \times 100 \%
$$

Satuan yang digunakan dalam rasio BOPO adalah persentase. Formulasi berdasarkan rumus sebagai berikut (Perda No 3 Tahun 2017)

$$
\text { BOPO }=\frac{\text { Biaya Operasional }}{\text { Pendapatan Operasional }} \times 100 \%
$$

Metode pengumpulan data yang digunakan dalam penelitian ini adalah metode observasi nonparticipant, yaitu peneliti tidak terlibat secara langsung dan hanya sebagai pengamat independen (Sugiyono, 2015:236). Dalam penelitian ini data yang digunakan berupa laporan keuangan LPD di Kabupaten Karangasem periode 2015-2017. Metode penentuan sampel yang digunakan dalam penelitian ini adalah mengunakan metode probability sampling dengan cluster random sampling (sampel menurut daerah). Populasi yang digunakan dalam penelitian ini adalah seluruh LPD di Kabupaten Karangasem yang menghasilkan profit berturutturut dengan melaporkan laporan keuangan pada periode 2015, 2016, dan 2017 yaitu sebanyak 147 LPD. Banyak sampel dalam penelitian ini yaitu sebanyak 108 sampel dari 8 Kecamatan dalam menentukan proporsi sampelnya peneliti menggunakan rumus Yamane, dimana perhitungannya sebagai berikut:

$$
n=\frac{N}{1+\left(N(e)^{2}\right)}=\frac{147}{1+\left(147(0,05)^{2}\right)}=108
$$

Teknik analisis data yang digunakan dalam penelitian ini adalah analisis regresi linier berganda. . Persamaan analisis regresi tersebut dapat dirumuskan: 


$$
\mathrm{Y}=\alpha+\mathrm{b} 1 \mathrm{X} 1+\mathrm{b} 2 \mathrm{X} 2+\mathrm{b} 3 \mathrm{X} 3+\mathrm{b} 4 \mathrm{X} 4+\mathrm{ei}
$$

Keterangan :

$\begin{array}{lll}\mathrm{Y} & =\text { Variabel Profitabilitas LPD } \\ \alpha & =\text { Konstanta } \\ \mathrm{b} 1, \mathrm{~b} 2, \mathrm{~b} 3, \mathrm{~b} 4 & =\text { Koefisien Regresi }(\mathrm{X} 1, \mathrm{X} 2, \mathrm{X} 3, \mathrm{X} 4) \\ \mathrm{X} 1 & & =\text { Kecukupan Modal } \\ \mathrm{X} 2 & & =\text { Risiko Kredit } \\ \mathrm{X} 3 & & \text { Likuiditas } \\ \mathrm{X} 4 & & =\text { Efisiensi Operasional } \\ \mathrm{e} & & \text { Error }\end{array}$

\section{HASIL DAN PEMBAHASAN}

Penyajian statistik deskriptif dilakukan untuk menginformasikan karakteristik variabel-variabel penelitian, seperti nilai terkecil, nilai terbesar, ratarata dan standar deviasi. Variabel-variabel tersebut terdiri dari kecukupan modal (CAR), risiko kredit (NPL), likuiditas (LDR), efisiensi operasional (BOPO) dan profitabilitas (ROA) yang terlihat dari Tabel berikut:

Tabel 4.

Uji Statistik Deskriptif

\begin{tabular}{llrrrr}
\hline & N & \multicolumn{1}{c}{ Minimum } & \multicolumn{1}{c}{ Maximum } & \multicolumn{1}{c}{ Mean } & Std. Deviation \\
\hline CAR & 324 &, 045 & 1,015 &, 21477 &, 148127 \\
NPL & 324 & 0,000 &, 986 &, 09923 &, 139267 \\
LDR & 324 &, 351 & 2,954 &, 78358 &, 253186 \\
BOPO & 324 &, 018 &, 961 &, 74956 &, 132608 \\
ROA & 324 &, 002 &, 199 &, 03710 &, 023492 \\
Valid N (listwise) & 324 & & & &
\end{tabular}

Sumber: Data diolah, 2018

Profitabilitas (ROA) memiliki nilai minimum 0,002 yang dimiliki oleh LPD pemuteran pada tahun 2017. Nilai maksimum sebesar 0,199 yang dimiliki oleh LPD Pule pada tahun 2015. Nilai rata-rata profitabilitas (ROA) sebesar 0,03710 dengan nilai standar deviasi sebesar 0,023492 artinya terjadi penyimpangan nilai profitabilitas terhadap nilai rata - ratanya sebesar 0,023492 atau 23,492 persen.

Kecukupan modal diukur dengan capital adequacy ratio (CAR) yang merupakan rasio kewajiban pemenuhan modal minimum yang harus dimiliki oleh LPD dalam permodalan yang ada untuk menutupi kemungkinan kerugian dalam sistem perkreditan. CAR dalam penelitian ini adalah CAR LPD seKabupaten Karangasem periode 2015-2017. Perkembangan CAR pada LPD se-Kabupaten Karangasem dapat dilihat yaitu nilai minimum CAR atau nilai terendah sebesar 0,045 yang dimiliki oleh LPD Sangkan Gunung pada tahun 2015 sebesar 4,46 persen yang berarti setiap Rp. 1 persen aktiva berisiko dijamin oleh Rp. 0,045 modal. Nilai maksimum CAR sebesar 1,015 yang dimiliki oleh LPD Tulamben pada tahun 2016 sebesar 101,53 persen yang berarti setiap Rp. 1 aktiva berisiko dijamin oleh Rp 1,015 modal. Berdasarkan Tabel 4, dapat dilihat bahwa rata-rata 
CAR sebesar 0,21477 dan nilai standar deviasi dari CAR sebesar 0,148 artinya terjadi penyimpangan nilai CAR terhadap nilai rata - ratanya sebesar 0,148 .

Risiko Kredit yang dilihat dari NPL merupakan risiko kerugian yang dialami oleh LPD melalui kredit yang disalurkan kemasyarakat yang disebabkan oleh ketidakmampuan debitur untuk memenuhi kewajibannya dalam pembayaran utang baik berupa utang pokok maupun bunga. Dapat dilihat bahwaa NPL memiliki nilai minimum sebesar 0,000 . Nilai maksimum NPL 0,986 yang dimiliki oleh LPD Pemuteran pada tahun 2017 sebesar 0,986. Bedasarkan Tabel 4 nilai rata-rata NPL sebesar 0,099 dengan standar deviasi sebesar 0,139 artinya terjadi penyimpangan nilai risiko kredit terhadap nilai rata - ratanya sebesar 0,139 .

Likuiditas yang diproksikan menggunakan LDR yang menunjukkan seberapa likuid suatu LPD. Ketentuan Bank Indonesia kisaran LDR harus dipelihara LPD adalah 78 persen-92 persen. Semakin tinggi tingkat LDR semakin illikuid suatu LPD, dalam keadaan seperti ini LPD akan kesulitan memenuhi kewajibankewajiban jangka pendeknya karena banyaknya dana yang disalurkan seperti adanya penarikan secara tiba-tiba oleh nasabah. Semakin likuid suatu LPD itu menggambar banyak dana yang menganggur sehingga dapat memperkecil perolehan laba LPD. Maka dari itu tingkat LDR harus dijaga oleh LPD agar kepercayaan masyarakat terhadap lembaga semakin tinggi.

LDR dalam penelitian ini adalah LDR LPD se-Kabupaten Karangasem periode 2015-2017. Pada Lampiran 8 dapat dilihat rasio dari LDR dari masingmasing LPD. Nilai LDR terendah sebesar 0,351 yang dimiliki oleh LPD Rendang pada tahun 2015. Nilai maksimum LDR sebesar 2,954 yang dimiliki oleh LPD Tenganan Pagringsingan pada tahun 2017. Nilai rata-rata LDR sebesar 0,78358 dengan standar deviasi sebesar 0,253186 artinya terjadi penyimpangan nilai likuiditas terhadap nilai rata - ratanya sebesar 0,253186 .

Efisiensi Operasional terlihat pada sisi laba rugi LPD dimana terdapat sisi biaya operasional dan pendapatan operasional. Jika baaya operasional LPD lebih besar daripada pendapatan operasional atau pendapatan yang dihasilkan sedikit, maka LPD tersebut tergolong tidak efisien. Nilai rasio BOPO yang ideal berada pada kisaran 50-75 persen sesuai dengan ketentuan Bank Indonesia. Dapat dilihat rasio BOPO masing masing LPD. Nilai rasio BOPO minimum sebesar 0,018. Nilai maksimum sebesar 0,961 dan nilai rata-rata sebesar 0,74956 dengan standar deviasi sebesar 0,132608artinya terjadi penyimpangan nilai efisiensi operasional terhadap nilai rata - ratanya sebesar 0,132608

Tabel 5.

Hasil Uji Regresi Linier Berganda

\begin{tabular}{llrrrrr}
\hline Model & \multicolumn{2}{c}{$\begin{array}{c}\text { Unstandardized } \\
\text { Coefficients }\end{array}$} & $\begin{array}{c}\text { Standardized } \\
\text { Coefficients } \\
\text { Beta }\end{array}$ & t & Sig. \\
& \multicolumn{1}{c}{ B } & \multicolumn{1}{c}{ Std. Error } & \multicolumn{2}{c}{} & \\
\hline 1 & (Constant) & .044 & .003 & & 13.643 & .000 \\
& CAR & .035 & .004 & .393 & 8.280 & .000 \\
& NPL & -.012 & .004 & -.131 & -3.031 & .003 \\
& LDR & .001 & .000 & .112 & 2.608 & .010 \\
BOPO & -.028 & .004 & -.365 & -7.669 & .000 \\
\hline
\end{tabular}

Sumber: Data diolah, 2018 


$$
\mathrm{Y}=0,044+0,035 \mathrm{X}_{1}-0,012 \mathrm{X}_{2}+0,001 \mathrm{X}_{3}-0,028 \mathrm{X}_{4}+\mathrm{e}
$$

Koefisien regresi variabel Kecukupan Modal sebesar 0,035 memiliki arti apabila kecukupan modal meningkat satu persen maka profitabilitas meningkat sebesar 3,5 persen dengan asumsi variabel lainnya konstan. Koefisien regresi variabel Risiko Kredit sebesar - 0,012 memiliki arti apabila Risiko Kredit meningkat satu persen maka profitabilitas menurun sebesar 1,2 persen dengan asumsi variabel lainnya konstan. Koefisien regresi variabel Likuiditas sebesar 0,001 memiliki arti apabila likuiditas meningkat satu persen maka profitabilitas meningkat sebesar 0,1 persen dengan asumsi variabel lainnya konstan. Koefisien regresi variabel efisiensi operasional sebesar - 0,028 memiliki arti apabila Efisiensi Operasional meningkat satu persen maka profitabilitas menurun sebesar 2,8 persen dengan asumsi variabel lainnya konstan.

Persamaan regresi tersebut menunjukkan arah pengaruh masing-masing variabel bebas terhadap variabel terikat. Hasil tersebut masih perlu ditinjau dengan hasil uji statistik selanjutnya yaitu uji pengaruh secara parsial masing-masing variabel bebas terhadap varibel terikat.

Nilai koefisien determinasi adalah antar nol sampai satu $\left(0<\mathrm{R}^{2}<1\right)$. Nilai $\mathrm{R}^{2}$ yang kecil berarti mempunyai kemampuan variabel-variabel independen dalam menjelaskan variasi dependen sangat terbatas. Nilai yang mendekati satu berarti variabel-variabel independen dapat memberikan hampir semua informasi yang dibutuhkan untuk menerangkan variabel dependen. Koefisien determinasi dapat dilihat melalui nilai adjusted $\mathrm{R}^{2}$. Hasil ujikoefisien determinasi dapat dilihat pada Tabel 5 sebagai berikut

Tabel 5.

Hasil Uji Koefisien Determinasi

\begin{tabular}{lcccc}
\hline Model & R & R Square & $\begin{array}{c}\text { Adjusted R } \\
\text { Square }\end{array}$ & $\begin{array}{c}\text { Std. Error of the } \\
\text { Estimate }\end{array}$ \\
\hline 1 & $.662^{\mathrm{a}}$ & .439 & .432 & .009886 \\
\hline
\end{tabular}

Sumber: Data diolah, 2018

Berdasarkan Tabel 5. dapat diamati nilai adjused $\mathrm{R}^{2}$ sebesar 0,432 berarti 43,2 persen perubahan (naik turun) pada Profitabilitas yang dipengaruhi oleh Kecukupan Modal, Risiko Kredit, Likuiditas dan efisiensi operasional sementara sisanya sejumlah 56,8 persen dipengaruhi oleh faktor - faktor lain diluar penelitian ini.

Berdasarkan hasil penelitian pengaruh kecukupan modal terhadap profitabilitas LPD di Kabupaten Karangasem diperoleh variabel kecukupan modal berpengaruh positif dan signifikan terhadap profitabilitas. Arah dari regresi yang positif menunjukkan bahwa semakin tinggi nilai kecukupan modal yang diproksikan dengan CAR maka profitabilitas yang dihasilkan juga akan meningkat. Hal tersebut berarti variabel kecukupan modal berpengaruh terhadap adanya kenaikan profitabilitas.

Kecukupan modal berfungsi untuk menutupi terjadinya risiko kerugiaan dari aktivitas yang dilakukan oleh LPD terutama dalam pemberian kredit sebagai pendapatan utama dari LPD. Semakin tingginya tingkat permodalan maka 
profitabilitas LPD semakin meningkat pula, begitu juga sebaliknya apabilai tingkat permodalan menurun maka akan menurunkan tingkat profitabilitas LPD.

Hasil penelitian ini juga didukung oleh penelitian yang dilakukan Capraru \& Ihnatov (2014), Houssem (2014), Roman \& Danuletiu (2013), Francis (2013), Damayanti (2012), Ani et al. (2012) menemukan bahwa capital adequacy ratio berpengaruh positif dan signifikan terhadap profitabilitas (ROA).

Berdasarkan hasil analisis pengaruh risiko kredit terhadap profitabilitas. diperoleh hasil nilai koefisien regresi sebesar $-0,012$ dengan nilai signifikansi sebesar 0,003 . Nilai koefisien regresi $<0$ dan nilai signifikansi $<0,05$ sehingga $\mathrm{H}_{2}$ diterima dan $\mathrm{H}_{0}$ ditolak, yang mengindikasikan bahwa risiko kredit berpengaruh negatif dan signifikan terhadap Profitabilitas. Itu berarti, semakin kecilnya nilai dari NPL maka semakin baik pula kinerja dari LPD tersebut sehingga dapat meningkatkan perolehan laba. Begitu juga sebaliknya apabila semakin tingginya nilai dari NPL maka semakin tinggi pula risko kredit yang dihadapi LPD sehingga dapat menurunkan perolehan laba melaui kredit yang disalurkan.

Hasil Penelitian ini didukung oleh penelitian yang dilakukan Peling \& Sedana (2018), Yanti (2015), Anggreni \& Suardhika (2014), Roman \& Danuletiu (2013) ,dan Sukma (2013) yang menemukan bahwa risiko kredit bepengaruh negatif signifikan terhadap profitablitas.

Berdasarkan hasil analisis pengaruh likuiditas terhadap profitabilitas, diperoleh hasil nilai koefisien regresi sebesar 0,001 dengan nilai signifikansi sebesar 0,010 . Nilai koefisien regresi $>0$ dan nilai signifikansi $<0,05$ sehingga $\mathrm{H}_{3}$ diterima dan $\mathrm{H}_{0}$ ditolak, yang mengindikasikan bahwa likuiditas berpengaruh positif dan signifikan terhadap profitabilitas. Itu berarti, apabila terjadi peningkatan LDR maka propfitabilitas ROA juga mengalami peningkatan. LPD yang dapat memenuhi likuiditas atau tidak memiliki masalah kekurangan likuiditas akan memberikan dampak yang positif terhadap kepercayaan dari masyarakat sehingga kesempatan LPD untuk memperoleh laba sangat besar. Hasil penelitian ini didukung oleh penelitian yang dilakukan Cristina \& Artini (2018), Peling \& Sedana (2018), Asri \& Suarjaya (2018) dan (Damayanti, 2012) menemukan bahwa likuiditas (LDR) berpengaruh positif dan signifikan terhadap profitbilitas.

Berdasarkan hasil analisis pengaruh efisiensi operasional terhadap profitabilitas, diperoleh hasil nilai koefisien regresi sebesar $-0,025$ dengan nilai signifikansi sebesar 0,000 . Nilai koefisien regresi $<0$ dan nilai signifikansi $<0,05$ sehingga $\mathrm{H}_{4}$ diterima dan $\mathrm{H}_{0}$ ditolak, yang mengindikasikan bahwa efisiensi operasional berpengaruh negatif dan signifikan terhadap profitabilitas. Itu berarti, semakin rendahnya biaya operasional akan dapa meningkatkan pendapatan dari LPD, begitu juga sebaliknya apabila terjadi peningkatan biaya operasional yang dikeluarkan maka akan menurunkan pendapatan dari LPD. Hal ini berarti peningkatan biaya operasional akan menurunkan pendapatan Bank, bank harus melakukan identifikasi sumber-sumber dari risiko operasional dan memonitor pelaksanaan proses dan sistem operasional bank sehingga pengeluaran biaya dapat diminimalkan (Peling \& Sedana, 2018). Hasil penelitian ini didukung oleh penelitian yang dilakukan Peling \& Sedana (2018), Prasetyo \& Darmayanti (2015), Zulfiah \& Joni (2014) menemukan bahwa BOPO berpengaruh negatif dan signifikan terhadap profitabilitas. 
Penelitian ini membahas tentang pengaruh kecukupan modal, risiko kredit, likuiditas, dan efisiensi operasional terhadap LDP di Kabupaten Karangasem. Hasil penelitian ini menunjukkan bahwa permodalan, risiko kredit, likuiditas, dan efisiensi operasional berpengaruh signifikan terhadap profitabilitas, sehingga variabel tersebut perlu diperhatikan oleh pihak LPD dalam meningkatkan profitabilitas.

Kecukupan modal berpengaruh positif dan signifikan terhadap profitabilitas LPD di Kabupaten Karangasem. Jika tingkat permodalan dari LPD tinggi, maka semakin tinggi pula tingkat profitabilitas dan LPD mampu menutupi biaya dari aktivitas kegiatan operasionalnnya. Permodalan salah satu faktor yang terpenting harus dimiliki oleh LPD karena permodalan akan mempengaruhi profitabiitas. Modal yang besar dimiliki oleh LPD dapat melindungi LPD dari risiko kerugian dalam melakukan kegiatan operasinal.

Risiko kredit yang di proksikan dengan NPL berpengaruh negatif dan signifikan terhadap profitabilitas LPD di Kabupaten Karangasem. Tinggi rendahnya tingkat NPL akan memepengaruhi profitabilitas LPD. Risiko kredit merupakan faktor penting yang mesti diperhatikan oleh pihak LPD, karena jika terjadi kredit bermasalah melalui kredit yang disalurkan maka LPD akan mengalami penurunan pendapatan yang diperoleh. Hal itu akan berimplikasi terhadap profit yang sudah ditargetkan melalui kredit yang disalurkan oleh LPD.

Likuiditas yang diproksikan dengan LDR berpengaruh positif dan signifikan terhadap profitabilitas LPD di Kabupaten Karangasem. Tinggi rendahnya tingkat rasio LDR suatu LPD akan mempengaruhi profitabilitas LPD. Bagi pihak LPD LDR merupakan variabel yang penting dalam mempengaruhi profitabilitas, karena kemampuan LPD dalam mengelola likuiditas akan berdampak terhadap kepercayaan masyarakat kepada LPD itu sendiri, sehingga akan membantu kelangsungan operasionalnya maupun keberadaan LPD tersebut. Jika LDR dari LPD rendah maka banyak dana yang belum disalurkan oleh pihak LPD sehingga akan berdampak pada perolehan profitabilitas.

Efisiensi operasional merupakan perbandingan dari biaya operasional terhadap pendapatan operasional (BOPO). Untuk meningkatkan profitabilitas LPD harus memperhatikan rasio BOPO. BOPO dalam penelitian ini berpengaruh negatif dan signifikan terhadap profitabilitas. Faktor ini yang harus diperhatikan juga oleh pihak LPD, karena apabila terjadinya peningkatan rasio BOPO maka akan menurunkan pendapatan LPD begitu juga sebaliknya.

\section{SIMPULAN}

Kecukupan Modal berpengaruh positif dan signifikan terhadap profitabilitas. Hal ini berarti apabila permodalan semakin meningkat maka Profitabilitas semakin meningkat pula. Maka jika tingkat modal tinggi berarti LPD mampu membiayai kegiatan operasionalnya sehingga kemampuan LPD dalam memperoleh laba juga akan meningkat.

Risiko Kredit dilihat dari rasio non performing loan (NPL) berpengaruh negatif dan signifikan terhadap profitabilitas. Hal ini berarti apabila Risiko Kredit semakin meningkat maka Profitabilitas semakin menurun, karena jumlah modalnya akan berkurang yang digunakan untuk menutupi tingginya rasio kredit bermasalah yang seharusnya pendapatan tersebut diperoleh oleh LPD. 
Likuiditas berpengaruh positif dan signifikan terhadap profitabilitas. Hal ini berarti apabila Likuiditas semakin meningkat maka Profitabilitas semakin meningkat pula. LPD yang tidak mempunyai kekurangan likuiditas akan memberikan damapk positif terhadap kepercayaan masyarakat sehingga kemampuan LPD dalam memperolh laba juga akan meningkat.

Efisiensi operasional berpengaruh negatif dan signifikan terhadap profitabilitas. Apabila efisiensi operasional semakin meningkat maka Profitabilitas semakin menurun. Hal ini berarti tingginya biaya operasional yang dibebankan maka akan menurunkan pendapatan yang diperoleh oleh LPD.

LPD se- Kabupaten Karangasem sebaiknya mempertahankan serta mengoptimalkan variabel kecukupan modal (CAR), risiko kredit (NPL), likuiditas (LDR), dan efisisiensi operasional (BOPO). Berdasarkan penelitian yang dilakukan keempat variabel ini memiliki pengaruh yang signifikan terhadap profit yang akan dihasilkan oleh LPD di Kabupaten Karangasem.

Penelitian ini hanya meneliti variabel kecukupan modal (CAR), risiko kredit (NPL), likuiditas (LDR), dan efisiensi operasional (BOPO) dan profitabilitas (ROA). Diharapkan bagi peneliti selanjutanya agar dapat menambahkan variabelvariabel lainnya yang tidak digunakan dalam penelitian ini, seperti cash turnover, net interest margin, dana pihak ketiga serta diharapkan mampu menambah referensi terhadap variabel-variabel yang akan diteliti.

\section{REFERENSI}

Almumani, M. A. (2013). Impact of Managerial Factors on Commercial Bank Profitability: Empirical Evidence from Jordan. International Journal of Academic Research in Accounting, Finance and Management Sciences, 3(3), 298-310.

Alper, D., \& Anbar, A. (2011). Bank Specific And Macroeconomic Determinants Of Commercial Bank Profitability: Empirical Evidence From Turkey. Business and Economics Research Journal, 2(2), 139-152.

Anggreni, M. R., \& Suardhika, I. M. S. (2014). Pengaruh Dana Pihak Ketiga, Kecukupan Modal, Risiko Kredit dan Suku Bunga Kredit pada Profitabilitas. E-Jurnal Akuntansi Universitas Udayana, 9(10), 27-38.

Ani, W. U., Ugwunta, D. O., Ezeudu, I. J., \& Ugwuanyi, G. O. (2012). An empirical assessment of the determinants of bank profitability in Nigeria: Bank characteristics panel evidence. Journal of Accounting and Taxation, 4(3), 3843.

Anjani, D. A. (2014). Pengaruh Non Performing Loan (NPL), Likuiditas dan Rentabilitas Terhadap Rasio Kecukupan Modal. E-Jurnal Manajemen Universitas Udayana, 3(4), 1140-1155.

Asri, N. N. sri, \& Suarjaya, A. G. (2018). Pengaruh Dana Pihak Ketiga, Capital Adequacy Ratio, Likuiditas, Dan Ukuran Perusahaan Terhadap Profitabilitas. 
E-Jurnal Manajemen Unud, 7(6), 3384-341.

Brigham, E. F., \& Houston, F. J. (2009). Dasar-Dasar Manajemen Keuangan Edisi Kesepuluh Buku Dua. Jakarta: Salemba Empat.

Capraru, B., \& Ihnatov, I. (2014). Banks' Profitability in Selected Central and Eastern European Countries. Economics and Finance 16, 1(1), 587-591.

Cristina, K. M., \& Artini, L. G. S. (2018). Pengaruh Likuiditas, Risiko Kredit, dan Dana Pihak Ketiga Terhadap Profitabilitas Pada Bank Perkreditan Rakyat (BPR). E-Jurnal Manajemen Unud, 7(6), 3353-338.

Damayanti, P. S. (2012). Analisis Pengaruh Ukuran (Size), Capital Adequacy Ratio (CAR), Pertumbuhan Deposit, Loan To Deposit Rasio (LDR), Terhadap Profitabilitas Perbankan Go Public Di Indonesia tahun 2005 - 2009. Jurnal Ilmu Manajemen Dan Akuntansi Terapan (JIMAT), 3(2), 45-54.

Dendawijaya, L. (2005). Manajemen Perbankan. Jakarta: Ghalia Indonesia. , L. (2009). Manajemen Perbankan. Jakarta: Ghalia Indonesia.

Duraj, B., \& Moci, E. (2015). Factors Influencing The Bank Profitability Empirical Evidence From Albania. Asian Economic and Financial Review, 5(3), 483-494.

Francis, M. E. (2013). Determinants of Commercial Bank Profitability in SubSaharan Africa. International Journal of Economics and Finance, 5(9), 134147.

Houssem, R. (2014). What Determines the Profitability of Banks During and before the International Financial Crisis? Evidence from Tunisia. International Journal of Economics, Finance and Management, 2(4), 330-337.

Ismail. (2009). Akuntansi Bank: Teori dan Aplikasi dalam Rupiah. Jakarta: Kencana.

Kasmir. (2012). Bank \& Lembaga Keuangan Lainnya. Jakarta: PT. Raja Grafindo Persada.

Peling, I. A. A., \& Sedana, I. B. P. (2018). Pengaruh LDR, NPL, dan BOPO Terhadap Profitabilitas Pada PT. BPD Bali Periode Tahun 2009-2016. EJurnal Manajemen Unud, 7(6), 2999-3026.

Peraturan Daerah Provinsi Bali Nomor 3 Tahun 2017 tentang Lembaga Perkreditan Desa dan Peraturan Gubernur Bali Nomor 44 Tahun 2017 tentang Peraturan Pelaksanaan Peraturan Daerah Provinsi Bali Nomor 3 Tahun 2017. Biro 
Perekonomian Setda Provinsi Bali 2017

Porawouw, M. A. (2014). The Application of Camel Model on Bank Listed in Indonesia Stock Exchange period 2008-2010. International Business Administration Journal University of Sam Ratulangi Manado, 2(1), 124-233.

Prasanjaya, A. A. Y., \& Ramantha, I. W. (2013). Analisis Pengaruh Rasio CAR, BOPO, LDR dan Ukuran Perusahaan Terhadap Profitabilitas Bank yang Terdaftar di BEI. E-Jurnal Akuntansi Universitas Udayana, 4(1), 230-245.

Prasetyo, D. A., \& Darmayanti, N. P. A. (2015). Pengaruh Risiko Kredit, Likuiditas, Kecukupan Modal, dan Efisiensi Operasional Terhadap Profitabilitas Pada PT BPD Bali. E-Jurnal Manajemen Unud, 4(9), 2590-2617.

Pratiwi, L. P. S. W. (2015). Pengaruh CAR, BOPO, NPL, dan LDR Terhadap Profitabilitas. E-Jurnal Manajemen Unud, 5(4), 2137-2166.

Putrianingsih, D. I. (2016). Pengaruh Non Performing Loan dan Capital Adequacy Ratio terhadap Profitabilitas. Management Analysis Journal, 5(2), 110-115.

Rengasamy, D. (2014). Impact of Loan Deposit Ratio (LDR) on Profitability: Panel Evidence From Commercial Banks in Malaysia. In Poceedings of the Third Internatinal Conference on Global Business, Economics, Finance and Social Sciences (GB14Mumbai Conference) (pp. 1-12). Mumbai, India.

Riyadi, S. (2006). Banking Assets and Liability Management. Jakarta: FEUI.

Roman, A., \& Danuletiu, E. A. (2013). Empirical Analysis Of The Determinants Of Bank Profitability In Romania. Annales Universitatis Apulensis Series Oeconomica, 15(2), 580-593.

Sudirman, I. W. (2013). Manajemen Perbankan Edisi Pertama. Denpasar: Balai Pustaka.

Sujana, I. P. C. (2014). Pengaruh Cash Turnover, Loan to Deposit Ratio, Capital Adequacy Ratio, dan Dana Pihak Ketiga terhadap Profitabilitas LPD. Jurnal Strategi Bisnis Dan Kewirausahaan, 8(2), 101-108.

Sukma, Y. (2013). Pengaruh Dana Pihak Ketiga, Kecukupan Modal, dan Risiko Kredit Tehadap Profitabilitas. Jurnal Akutansi Universitas Negeri Padang, 1(2), 1-27.

Wiagustini, L. P. (2014). Manajemen Keuangan. Denpasar: Udayana University Press.

Wibowo, E. S. M. S. (2013). Analisis Pengaruh Suku Bunga, Inflasi, CAR, BOPO, NPF Terhadap Profitabilitas Bank Syariah. Diponegoro Journal Of 
E-Jurnal Manajemen, Vol. 8, No. 10, 2019 : 6022-6041

Management, 2(2), 1-10.

Yanti, F. A. K. (2015). Pengaruh Dana Pihak Ketiga, Kecukupan Modal, Risiko Kredit dan Likuiditas Terhadap Profitabilitas LPD Kabupaten Badung. EJurnal Manajemen Unud, 4(12), 4362-4391.

Zulfiah, F., \& Joni, S. (2014). Pengaruh Inflasi, BI Rate, BI Rate, Capital Adequacy Ratio (CAR), Non Performing Finance (NPF), Biaya Operasional dan Pendapatan Operasional (BOPO) Terhadap Profitabilitas Bank UmumSyariah Periode 2008-2012. Jurnal Ilmu Manajemen, 2(3), 1-5. 